William Shakespeare's New Place: investing in, or inheriting a legacy?

William Mitchell

Project Archaeologist. The Centre of Archaeology, Staffordshire University

11351 Words (References; 1071Words)

William Mitchell

Department of Humanities and Performing Arts,

Staffordshire University,

Flaxman Building,

College Road,

Stoke-on-Trent,

ST4 2DE.

William.Mitchell@staffs.ac.uk

01782295823 


\section{William Shakespeare's New Place: investing in, or inheriting a legacy?}

\section{By WILLIAM MITCHELL}

SUMMARY: New Place is the name of the house that William Shakespeare purchased in 1597 and the place in which he died in 1616. The house was constructed in Stratford-upon-Avon over a century previously but had disappeared by 1759 leaving only an empty gap in the street frontage. How much time Shakespeare spent there has long been debated but recent excavation and analysis of the surviving evidence has led to the notion that New Place was carefully chosen by Shakespeare to be his primary residence and the place to live with his family and compose much of his later writing. The importance of Hugh Clopton, the former owner and builder of New Place, and the welcome associations which his name brought to the property, is also debated here. Shakespeare's motives, his pursuit of status, desire for investment and obligation to his family are all explored through the use of archaeological data and the historical evidence for the house.

\section{INTRODUCTION}

Buildings, through their occupants' practice of everyday activities and ingrained habits of mind, are imbued with symbolism and expectations that carry social weight, which in turn inform and mediate the actions undertaken within and around them. To understand a building we must understand its occupants and vice versa. ${ }^{1}$

The building in question is New Place and its occupant is William Shakespeare. New Place, which once stood in the heart of Stratford-upon-Avon, has long been regarded as significant and its legacy has been assured as a direct result of its most famous resident. A greater understanding of this lost property has been made possible through an archaeological investigation of the site, which took place intermittently from 2010 to 2015 . The resulting evidence has led to the suggestion that, for Shakespeare, this building represented not only a place to live but also a place which held valued and welcome symbolic associations.

This paper looks at the motives behind Shakespeare's purchase and the resulting consequences of this, both for Shakespeare as an individual and for the Shakespeare family name. His pursuit of status, his desire for investment and his obligation to his family are all considered as reasons behind his purchase of New Place. 
The origin and development of New Place is complex and has involved other influential figures, foremost among these was Hugh Clopton, the 15th-century owner and architect of the building. The influence of Hugh Clopton is cited as an important aspect in the discussion surrounding Shakespeare's purchase and that these two men, who followed comparable but distinct paths, are inexorably linked by their association with this important building.

This paper argues that Shakespeare deliberately used the appearance and stature of the house and the reputation of its previous influential owner, to establish his own local and regional status and to distinguish the Shakespeare family name. Hugh Clopton's gentry status is considered an aspiration to Shakespeare as was his merchant occupation, which was of direct relevance to Shakespeare's family circumstance. Rather than construct a new house on a vacant plot in Stratford-upon-Avon, the heritage of New Place and the symbolic association of Hugh Clopton, which endured the passage of time, was welcomed by Shakespeare and became a desirable reason for his famous purchase.

The form and function of New Place, which was ultimately a product of Hugh Clopton's vision, provided William Shakespeare with the opportunity to inherit its established heritage and craft his own version of New Place. In renovating the late medieval house, Shakespeare was able to embrace the latest fashions of his day whilst still keeping faithful to the traditions of his ancestors. The developed form of New Place provides evidence 'beyond his work as a poet and dramatist, of a project on which Shakespeare focused his creative imagination'. ${ }^{2}$

This paper also looks at William Shakespeare's influence within the context of his family and attempts to highlight Shakespeare's additional financial investments, culminating in the purchase of New Place.

The recent archaeological work ${ }^{3}$ has confirmed the presence of an open-hall. The existence of this, along with Shakespeare's introduction of a long gallery and the associations between New Place and performance spaces such as the courtyard inns of London and elsewhere, add a further dimension to the possible reasoning behind Shakespeare's purchase.

The resulting insights enable us to discover Shakespeare's attitudes towards his life at a particular point in time. Little is known about the social and emotional life of Shakespeare, so attempts to recount these aspects must depend upon reviewing surviving evidence and by 
placing him firmly within the known attitudes of the time in which he lived. New Place is used as a physical artefact as a means to view William Shakespeare's decision making and personal values.

During his tenure of New Place, William Shakespeare is known to have written the greater majority of his major works, many of which could have been composed within the comfort of his own home, away from the distractions of his busy London life. Past suggestion had been that Shakespeare spent very little time at New Place, preferring to live and work in London, eventually 'retiring' to New Place around 1610, living there with his family until his death in 1616. Part of this supposition originates from the testimony of John Aubrey, who in the mid17th century was informed by neighbours of Shakespeare that he only returned home once a year. ${ }^{4}$ However, a greater understanding of the property, its medieval origins, unique character and splendour has been achieved through the recent investigations. This has led to the conclusion that Shakespeare would have intentionally chosen to spend a significant amount of time there, perhaps returning home for extended periods annually, initially in the planned or forced closed theatre seasons, using this time to complete his writing.

\section{THE ARCHAEOLOGY OF NEW PLACE}

Archaeological evidence has illuminated the facts surrounding this lost Shakespearean property and has returned the house to the public's attention. The importance that the property had in Shakespeare's life has been clarified and as such, it should be restored to its rightful place in future biographies of the playwright.

The house known as New Place was erected at the centre of Stratford-upon-Avon, on the corner of Chapel Street and Chapel Lane adjacent to the 13th-century Guild Chapel and it has long been acknowledged as the location of William Shakespeare's final home (Fig. 1).

(Figure 1)

A current and up-to-date archaeological history and architectural description of the site of New Place has recently become possible. Investigations undertaken on the site have demonstrated that the story of New Place is far more complex than was previously believed and that the standard and accepted vision of Shakespeare's home should be revised. The results, available 
in Finding Shakespeare's New Place: an archaeological biography, ${ }^{5}$ present an archaeological, historical and architectural description of New Place. The purpose of this paper is to discuss the many and varied reasons surrounding Shakespeare's celebrated purchase.

In summary, the archaeological evidence has confirmed that New Place originated as a latemedieval open-hall house, constructed around a courtyard which was originally designed and built by the local influential merchant Hugh Clopton, over 100 years prior to Shakespeare's purchase. Traditional elements of medieval house-planning were present in the layout of Clopton's house; these included separate domestic rooms, such as the open-hall, buttery and pantry, kitchen and chambers. The existence of the courtyard with the open-hall behind was an unusual design element, seldom seen in small towns and usually reserved for high-ranking influential figures - a role which Clopton certainly fit. ${ }^{6}$

From the time of its conception New Place was unusual within Stratford-upon-Avon, being one of the largest domestic residences and the only courtyard-style, open-hall house within the borough. This architecturally striking style of house was typified by the merchant and upper classes and similar examples were to be found in trading centres across the country.

Shakespeare therefore purchased a house which already held architectural and symbolic importance in its own right. When Shakespeare bought the house in 1597, however, the house was no longer new and was in disrepair. Shakespeare seemingly used this opportunity to renovate and modernize the house in a desire to project his intended image and leave a lasting visual legacy for the Shakespeare family. The purchase and renovation of New Place would have enhanced both his own and his family's reputation in his lifetime, particularly within Stratford-upon-Avon, but also within the wider region of Warwickshire. Having invested heavily in the property, Shakespeare used the house layout to his advantage and created a family home and a place which portrayed the elite image he so desired.

Being a native of Stratford-upon-Avon, Shakespeare would have been aware of the reputation and status of the local Clopton family and its individual members, in particular, Hugh Clopton. It has been necessary to look in detail at the background of Clopton, in an attempt to identify reasons behind Shakespeare's purchase of New Place and offer an explanation as to the structure of the house which New Place represented. 


\section{HUGH CLOPTON AND NEW PLACE}

\section{A BRIEF HISTORY OF HUGH CLOPTON}

Hugh Clopton (c. 1440-96) belonged to a local influential family of landed gentry. He was the architect behind New Place and became a fondly regarded citizen of Stratford-upon-Avon. His family were of modest rank, they were influential in the local community but in the context of the noble Warwickshire families, not overly wealthy. Located a mile north of Stratford-uponAvon, their main residence, Clopton House, was known to have been occupied from at least the 1220s. Subsequent family members were to play an influential role in the history of Stratford-upon-Avon from this early period and beyond (Fig. 2).

(Figure 2)

Hugh Clopton left home aged 16 to become apprenticed to a London mercer, John Roo. He learned his craft and eventually his fortune, by trading in wool and wool cloth out of London to ports on the continent. ${ }^{7}$ Clopton gained influence in the merchant community and in 1464 became a member, and then warden $(1479,1485$ and 1488), of the company of Mercers. In 1469-70 he was admitted to the Stratford-upon-Avon Guild, ultimately serving as master for two years. As a merchant of the Woolstaple, Hugh Clopton was able to trade freely and amass his fortune. His name is recorded in the Exchequer Customs accounts for 1480-1 for shipping wool and animal hides to Calais from London. ${ }^{8}$ He subsequently achieved many official roles including Alderman, Sheriff, Member of Parliament and ambassador on behalf of Richard III, his professional career culminating in his election to Lord Mayor of London in $1491 .{ }^{9}$

The first specific mention of New Place occurs in Hugh Clopton's will of 1496, where he describes it as 'my grete house'. ${ }^{10}$ The property had been purpose-built several years previously in c. 1483 and was one of several that Clopton owned within the centre of town, some of which were premises he had inherited from his family. Perhaps, he named it his 'grete house' as a means of singling it out from his other lesser properties and as a result of a sentimental pride and personal investment in New Place. 
The career profile of Hugh Clopton suggests that he must have spent a significant amount of his time in London. The dates for his commitments in London cover the period from the late 1470s to early 1490s. During his time in London, he owned and occupied a house in Old Jury, (later the Windmill Inn). It is also known that he owned property in Calais, for the purpose of housing him during his merchant duties (Hugh Clopton's will). His time was likely to have been spent equally between London and Stratford-upon-Avon, while ultimately remaining committed to his London cause.

However, Stratford-upon-Avon was only a two- to three-day ride away and Clopton must have spent time here, his favoured place. His family influence and London connection would have seen him assume a position of authority whenever he arrived back in Stratford. He was in Stratford upon his election to Mayor in 1491, presumably at his home at New Place. This is witnessed by the fact that when he was elected, he was at the time in Stratford. Upon his return to London, in honour of the occasion, the company of mercers sent a delegation of 24 mercers to escort him the last ten miles $(16.1 \mathrm{~km})$ into the city. ${ }^{11}$

Hugh Clopton died in 1496, having accumulated a vast wealth. The actions he took during his life and the provisions of his will serve as a testimony of his loyalties to his home town of Stratford-upon-Avon. He was buried in London in St Margaret Lothbury church as his death occurred at his house in that parish. Had he died in Stratford-upon-Avon, he would have been buried there, at Holy Trinity Church, where his unoccupied tomb still survives today. This confirms he retained a shared work and domestic status between the two locations in Stratfordupon-Avon and London throughout life and death.

Hugh Clopton and his family had long been supporters of the Guild of the Holy Cross, a powerful religious institution. As well as his contributions towards the construction of the bridge over the Avon (Clopton Bridge) and the rebuilding of the nave, tower and porch of the Guild Chapel, Hugh Clopton also left money for the restoration of the transept of Holy Trinity Church. Substantial charitable bequests and endowments were made in Stratford, London, Oxford and Cambridge. These included 100 marks, which were to be laid out in dowries of five marks to 20 poor maidens of good name and fame dwelling within the town of Stratfordupon-Avon and $£ 100$ for distribution to the poor of the same town. He has also been credited with repairing the roads around Aylesbury, one of the towns on the regular route from London. ${ }^{12}$ 
Hugh Clopton's construction of New Place was a deliberate symbolic gesture and a means of asserting the Clopton family presence at a highly visible location within Stratford-upon-Avon. It ensured the family retained close links with the Guild, which was located next door and the opportunity to live and work within the heart of Stratford's wool trading centre.

At the turn of the 15th century, New Place would have appeared to the visitors of Stratfordupon-Avon as a distinctive and spectacular sight, worthy of Hugh Clopton's self-professed 'grete house' status. Hugh Clopton's influence within Stratford-upon-Avon was enduring. A description of Stratford-upon-Avon was recorded by John Leyland around the 1540s whilst undertaking his tours of England and Wales. This Itinerary, as it became known, listed the most imposing and memorable features of the town, the first of which, built by Hugh Clopton, was the bridge over the Avon (Fig. 3):

Wherapon in tyme of mynde one Cloptun, a great rich marchant, and Mayr of London, as I remember, borne about Stratforde, having never wife nor children converted a great peace of sumptuous new bridge and large of stone. ${ }^{13}$

(Figure 3)

Leyland also remarks on the other memorable features of Stratford-upon Avon, including the Guild Chapel, also redeveloped by Hugh Clopton:

There is a right goodly chappell in a faire streate toward the southe ende of the towne dedicate to the Trinitie. This chapel was newly reedified in mind of one Hughe Clopton, Major of London. ${ }^{14}$

Finally, New Place itself is mentioned, this being the earliest known description of its former appearance (Fig. 4):

This Clopton buildid also by the north syde of this chapel a praty howse of brike and tymbar, weherin he lay in his lattar dayes and dyed. ${ }^{15}$

(Figure 4) 
Clopton's contributions to the religious and secular architecture of Stratford-upon-Avon have been remembered by the citizens of Stratford-upon-Avon to this day and would have undoubtedly been appreciated both at the time and into Shakespeare's day, as represented in Leyland's writings. In particular, the replacement of the dilapidated timber bridge would have given Stratford-upon-Avon a much-sought trading advantage. However, recognition of Hugh Clopton's many achievements by the wider population have since been overlooked at the expense of William Shakespeare's unrivalled fame and accomplishments.

Much like William Shakespeare, Hugh Clopton has a similar right to be held in high regard by the people of Stratford-upon-Avon. Within the community of Stratford-upon-Avon, Hugh Clopton has become the most famous member of his family thanks to the contributions he made to Stratford-upon-Avon and beyond. As he was well known he is likely to have been looked at by Shakespeare as someone who could be admired and emulated. The name of Clopton has been immortalised within Stratford due to Hugh Clopton's achievements, he preserved his family name through his merchant activities, donations to the town and roles within London.

\section{HUGH CLOPTON'S NEW PLACE}

Hugh Clopton owned the family estate and several properties across Stratford-upon-Avon, which he had acquired through inheritance. New Place however, was Clopton's only purposebuilt house. Constructed within the centre of the small urbanized town, it was carefully designed and planned to be a symbolic expression of his wealth and status and was built with an aristocratic country house sentiment. The location for his house was carefully chosen, specifically for its large plot and the benefits that this particular plot brought, for example, being adjacent to the busy 'White Cross' market area on one of the main thoroughfares. It was also adjacent to the Guild, and as such this area provided a focus for the town from the late13th century onward. ${ }^{16}$

The courtyard design that Hugh Clopton chose for his main home in Stratford-upon-Avon was important, and stylistically relatively little has been written about this type of medieval urban house. The courtyard house was of a style which spread across the country throughout the 14th and 15th centuries and which had developed due to the influence of monastic and fortified castle buildings. Typically this style of house is of a type used in country settings on land 
where space was not at a premium, although there are well known examples of these in urban settings across the country.

Clopton's New Place was built around a central courtyard, enclosed on three sides by buildings and on a further side by the adjacent properties. The development of the domestic courtyard had been influenced by the style of monastic and fortified castle buildings and by the beginning of the 14th century the courtyard was the primary shape for most high status houses'. ${ }^{17}$

Hugh Clopton was likely to have encountered this type of building during his time living and working in London, in addition to travelling across England and Northern France. His decision to construct a courtyard house would have been influenced by his desire to imitate these buildings, assume the status which this type of house implied, and make a statement within the heart of his home town of Stratford-upon-Avon. Traditionally, the domestic architecture of the period was intended to be a reflection of religious and high-status examples. Members of other social classes sought to mimic the residences of these higher social classes.

New Place was accessed through a central gateway, within a range that fronted onto Chapel Street. This gatehouse building contained cellars beneath the southern part of the range, which were probably used for storage. It is probable that Hugh Clopton used the frontage range as shops, which he may have let out separately due to his commitments in London. ${ }^{18}$ Throughout his early career, Clopton's primary income was from the trade of wool, and he exported his wares to the continent. A number of lead cloth or bale seals, used for identification and as part of the regulation and quality control of the article contained within, were recovered from the site (Fig. 5 \& Fig. 6).

(Figure 5)

(Figure 6)

This format was a common occurrence as Pearson points out:

Dwellings often inhabited by wealthy merchants lay back from the street front, which was reserved for commercial activity. ${ }^{19}$ 
The halls of these properties were the focus of the house and played a prominent role in the planning of the building. The form of the New Place hall was that of a typical single-ended type, possibly open to the roof timbers, with the hall on one side of a screens-passage and service rooms on the other. ${ }^{20}$ This style of house was favoured by certain members of society including the merchant class:

The hall of the property lay normally at the rear of a yard, though occasionally to the side on restricted sites, with a range of buildings, (often separately let) fronting the street. Leaders of the merchant community in major towns, such as those who dealt in wine or some other aspect of royal service, also aspired to the style of house with a courtyard and an open hall of lofty proportions. ${ }^{21}$

\section{OTHER SIGNIFICANT OWNERS OF NEW PLACE}

New Place had several other owners in the period prior to Shakespeare's occupation. These individuals were all influential and whose wealth and social standing provided them the opportunity to seek and purchase a prestigious home. A cursory glance of these owners suggests that New Place attracted individuals from a particular tier of society. This is the result of the type of house that New Place was designed to be and the recognition it had achieved. In this list of previous owners we see figures from Tudor society who held influential positions in regional government and at court, all of whom had the wealth and status to merit ownership of New Place.

After the death of Hugh Clopton, New Place remained with the family and passed to his great nephew William Clopton, upon whose death in 1521 it passed to his wife Rose. In 1525 their son William Clopton inherited New Place when his mother died.

The house was leased for 'two lives' to Thomas Bentley between 1543 and 1549. Thomas Bentley was personal physician to Henry VIII and former president of the Royal college of Physicians and spent much time at court. Upon his retirement he chose to leave the capital and retired to the home of his family in Stratford-upon-Avon. Bentley's close connections to royalty rightly required a suitable prestigious house to reflect his high-ranking status. ${ }^{22}$ Upon Bentley's death, his widow and her second husband Richard Charnock occupied the house until 1558, during which time she brought an action to the courts complaining that Clopton 
was trying to illegally evict her. In response Clopton stated that the lease was effectively broken because Bentley had:

Left the said manor place in great ruin and decay and unrepaired and it doth remain unrepaired ever since...to the great damage and loss of thee defendant. ${ }^{23}$

In 1563 William Bott purchased the house from William Clopton after some dubious legal negotiations. Bott was himself an influential member of the Stratford-upon-Avon hierarchy, serving in the town council with Shakespeare's father John, he was not though, without his share of controversy, having been associated with the death of his daughter. ${ }^{24}$ In $1567 \mathrm{New}$ Place was then sold for $£ 40$ to William Underhill of the inner temple, a member of the legal profession and clark of the assizes at Warwick. It remained in the possession of the Underhill's until misfortunes afflicted the family in the $1580 \mathrm{~s} .{ }^{25}$ The history of New Place from this period becomes unclear until the purchase by William Shakespeare in 1597, when he purchased New Place at a reduced price partially as a result of unpaid tithes on the part of Underhill. ${ }^{26}$

\section{SHAKESPEARE AND NEW PLACE}

\section{PROPERTY AND LAND INVESTMENTS}

To develop an understanding of Shakespeare's domestic position it is important to look at the movements which Shakespeare made in the early years of his career and at the investments he made in the capital in advance of his purchase of New Place.

It is evident that compared to the frequent, sustained and substantial investments Shakespeare made within and surrounding his home town of Stratford-upon-Avon, the evidence for Shakespeare's residency in London is not suggestive of a deep commitment to living and settling in the capital. Much like Hugh Clopton, London represented Shakespeare's business stakes and the place which he could generate his wealth, make his money and consequently, support his family. There is no specific evidence that Shakespeare was present in London between 1604 and 1612, raising the possibility that throughout this period he made New Place his primary residence. It also remains plausible that he maximised his time spent at New Place by returning during the theatre off season, when he had time and freedom to write with 
reference books to hand, away from the distractions and interruptions of London life (although, the demands of his domestic and business life in Stratford may have encroached on this time).

Shakespeare purchased a single property in London in 1613. It was known as the Gatehouse, and was situated within Blackfriars, a convenient location for both the Blackfriars Theatre and Globe Theatre. Shakespeare bought the house from Henry Walker for $£ 140$. His intention may have been to use this as his London base but this was never the case and he rented it straight back to Walker, showing his business acumen; this property was left to Susanna, Shakespeare's daughter, in his will. It is probable that this purchase was a deliberate investment intended to generate revenue and increase his property portfolio, which would also raise his status as a gentleman. ${ }^{27}$

Shakespeare appeared determined to secure the future wealth of the family. In doing so he invested in land and property. The purchase of New Place in 1597 indicates Shakespeare's financial ability to invest. This he purchased for the likely sum of $£ 120$ ( $£ 60$ is recorded in the court fine). In addition to this, he had inherited properties on Henley Street. Later in 1602, a second fine was levied on the New Place property, this added two orchards to his purchase of 1597. At this time he also paid $£ 320$ to the Combe family for 107 acres of farmland in Old Stratford. Later that year he purchased a small cottage which stood within a quarter of acre of garden in Chapel Lane opposite New Place, on a lease from the manor of Rowington. ${ }^{28}$ Later in 1605 he spent another $£ 440$ on the outstanding term of a lease of tithes in Stratford parish, which brought in an income of about $£ 60$ a year. The ownership of farmland was traditionally seen as an important factor of a gentleman's estate and in these purchases, Shakespeare was making a statement.

In his property and land investments within Stratford-upon-Avon and to a much lesser extent, London, Shakespeare's prosperity and pursuit of his gentlemen title is clear to see. The purchase of New Place in 1597 enabled Shakespeare and his family to live handsomely in the second largest house in Stratford upon Avon. In this purchase, Shakespeare made his most significant and shrewd investment. Shakespeare acquired New Place from William Underhill, at a time which it was considered in need of urgent renovation, being semi-derelict, and thought to have lain empty for several years. Shakespeare's fortuitous purchase included 'one messuage, two barns, and two gardens with appurtenances' and the deed of purchase notes state that 'the same William Shakespeare gave the said William Underhill sixty pounds sterling' the 
true cost was concealed in the sale documents and was likely to be at least twice as much. ${ }^{29}$ These investments, along with the increasingly visible prosperity of the Shakespeare's, would have made the citizens of Stratford take notice. They would not have viewed Shakespeare as the genius poet and playwright that he was later to become known, but 'a wealthy citizen with one of the most expensive homes in town' ${ }^{30}$ Someone who could be a source of potential revenue through personal loans or business deals.

Shakespeare was known as an investor and the records support this. Shakespeare had invested in malt and it is recorded that in February 1598, ten quarters of corn and malt were stored in his barns at New Place, possibly for reselling. A prosecution followed as this was viewed as illegal hoarding. This was at a time when the population of Stratford were suffering due to a succession of bad harvests. ${ }^{31}$

\section{SHAKESPEARE'S RENOVATIONS OF NEW PLACE}

New Place provided William with a comfortable base in his home town to retreat to and write when away from London. The earliest reference to Shakespeare himself having renovated New Place is by Lewis Thobald in his edition of Shakespeare's works in 1733. This had been recounted from a family tradition by John Clopton (subsequent owner and rebuilder of New Place in 1702). He writes that Shakespeare 'repair'd it and modell'd it to his own mind'. ${ }^{32}$

Once renovations were complete, it is believed that Shakespeare's wife Anne and their children took New Place as their main residence, having previously lived at Henley Street with Shakespeare's parents and two of his brothers, Richard and Edmund. ${ }^{33}$ Owing to the size of New Place, it is possible that other members of his family took New Place to be their home. Katherine Scheil reminds us of the possibility that:

John Shakespeare could have lived at New Place from 1597 until his death in 1601; Mary Arden until her death in 1608; and Shakespeare's brothers Gilbert and Richard until their deaths in 1612 and 1613 respectively. Hall's Croft was not built before 1613 so it is likely that Susanna and John Hall lived in New Place from their marriage in 1607, during daughter Elizabeth's birth in 1608, and probably from 1616 onward, after Shakespeare's death. Judith Shakespeare may have lived there until her marriage to Thomas Quiney in $1616 .{ }^{34}$ 
It also appears that for some time Shakespeare used part of his property as lodgings for his relations, as his cousin Thomas Greene was certainly living at New Place for an extended period from 1604 until $1611 .^{35}$

Upon Shakespeare's possession of New Place, he proceeded to renovate and modernize. In addition to the elements of the house, which were in need of repair, the house frontage would have been specifically targeted by Shakespeare for redesign as a means to mark his new ownership. The outward appearance of the house held importance, projecting as it was designed, the status and wealth of the owner at any given time. It was imposing and was also considered to be practical, fit in with the surrounding building landscape, and be impressive for visitors, both of New Place and of Stratford-upon-Avon. Shakespeare would have been aware of the reputation of the house and the value it held for the residents of Stratford-uponAvon.

He deliberately avoided constructing an entirely new property, choosing instead to impress his mark on the historic New Place. His positive sentiment towards the house probably began in his youth, perhaps he had long aspired to owning such a prestigious property, especially one which was familiar to him and imbued in such local history and authority.

In 1737, the professional engraver, George Vertue, sketched a view of New Place and wrote a short description. His sketch has been drawn from the memory of a reliable source, that of Shakespeare Hart, the great-great-nephew of Shakespeare, who was 71 years old in 1737 . The description written beneath the sketch provides an informative vision of the property:

This the outward appearance towards the Street. the gate and entrance, / (at the Corner of chapel lane) the chapel X. founded by $\mathrm{Sr} \mathrm{Hu}$. Clopton. / who built it and the Bridge over Avon. / besides this front or outward gate there was before the House itself / (that Shakespear livd in.) within a little court yard. Grass growing / there - before the real dwelling house, this outside being only / a long gallery \&c for servants. ${ }^{36}$

The style of the house portrayed by Vertue is one typical of the second half of the 16th century, not of the late-15th century, suggesting that this part of Hugh Clopton's house had received significant refurbishment by William Shakespeare. Limited archaeological evidence supports this Shakespearean refurbishment. The cellar, located beneath the frontage and put in by Hugh Clopton showed evidence of development, a brick wall matching 17 th-century walls 
elsewhere on site was identified along with a tile-lined drainage channel which marked the easternmost extent of the frontage (Fig. 7).

(Figure 7)

The presence of gable-ended dormer and large symmetrically placed, mullioned windows set into square panel and herringbone timber framing, are a product of the 16th century.

Corroborative evidence supports the likelihood that the frontage, as sketched by Vertue, represents Shakespeare's own home-improvement. Vertue's use of the phrase 'a long gallery \& c (chambers?) for servants', is significant as long galleries were an architectural feature which, became increasing popular during the mid to late-16th century in high-status houses and which were becoming more popular in well-to-do urban houses. Certainly, Hugh Clopton would not have known a long gallery at New Place. ${ }^{37}$

A record for 12th January 1598 in the Stratford-upon-Avon Guild minutes and accounts records ten pence ' $p d$ to $\mathrm{mr}$ Shaxspere for on lod of ston'. ${ }^{38}$ One interpretation of this has been that this was Shakespeare clearing away the debris and surplus building material caused by his renovation of New Place. The allusions to malt being held in buildings on the premises, provide a further clue to the size and purpose of areas of his house. A survey of grain and malt stores in Stratford in 1598 confirm his possession of a barn and access to large quantities of farmed produce. ${ }^{39}$

It therefore appears that Shakespeare redeveloped New Place. Hugh Clopton's hall would have remained firmly at the heart of the house complex. In keeping with the period and other renovations made to the house, the internal arrangement of the hall space probably underwent a partial or more extensive redesign and modernisation. The service range was kept, undergoing several adaptations to suit the developments in Elizabethan lifestyle and architecture and the courtyard remained in an unaltered form. Overall, the house changed dramatically from the time of its construction, however the majority of the structural elements would have been familiar to its past owner Hugh Clopton (Fig. 8 \& Fig. 9).

(Figure 8)

(Figure 9) 


\section{THE APPEARANCE OF THE PROPERTY}

The layout of the property, including the type and arrangement of the rooms which Shakespeare purchased, was a direct development and evolution of the earlier medieval property. The period in which Shakespeare lived saw many changes in accepted conventions of house building, the purpose and function of many of the rooms had developed, along with the new attitudes towards interior decoration.

Many of the internal and external features from Hugh Clopton's earlier house were retained, to become incorporated into Shakespeare's Elizabethan property. Careful consideration would have been made of the general architectural advancements, societal developments and preferences of his time, in order that he could overtly display his wealth, status and aspirations.

The interior design of the house that Shakespeare developed and resided was not one which Hugh Clopton would have been familiar with, however the overall arrangement of the house would have been markedly similar, having been allowed to remain without significant alteration. But why had Shakespeare chosen to keep New Place relatively true to its original form? In modern day terms, Shakespeare had purchased a house of some vintage, immediately providing Shakespeare with a visible late-medieval inheritance so desired by him and his family (this can also be seen in his pursuit of the family coat of arms). New Place was able to provide the link to a noble medieval past so desired by Shakespeare. By purchasing a house with a hall, Shakespeare was able to use this as the showpiece of his home, a place to symbolise his prosperity, rise in status and a means by which he could hark back to the late-medieval past of his ancestors.

Shakespeare used his accumulated wealth to amass property and land within Stratford-uponAvon. These investments, particularly those of New Place and its surrounding lands, supported his family in his home town and promoted the family name. For his new home, Shakespeare wanted to impress his influence and as has been shown, he proceeded to modernize the frontage of New Place, and install a long gallery, as per the expectations of a well-to-do, fashionable and aspiring gentleman of his time. This went against the accepted practice of his fellow playwrights who were investing in property in London (Fig. 10). 
(Figure 10)

\section{USE OF THE SPACE IN NEW PLACE}

Shakespeare may have chosen New Place on the basis that it possessed a variety of different internal and external spaces, within which the necessary domestic activities could be undertaken. New Place contained spaces, which could be used to suit Shakespeare's entertaining, leisure and work requirements. Shakespeare himself then added to and adapted these spaces to suit his personal needs and undertake his favoured activities whist presenting a certain image of himself to society. The open hall, courtyard, newly built long gallery and other spaces would have been multi-functional and periodically evolving.

\section{THE OPEN HALL}

From the late-15th century onward, the function of the open hall steadily evolved from being the primary living, entertaining and eating room to become a largely symbolic space, used less frequently. It increasingly became seen more as a visual representation of wealth and a symbol of social standing. New Place and in particular the open hall, would have been large enough to accommodate meetings of the local gentry. Political, domestic and business activities would have all been carried out beneath the roof of the hall and the interior splendour is likely to have suited Shakespeare's local responsibilities and personal agenda. Suits of armour and weapons may have hung on the walls, used to evoke past family achievements. ${ }^{40}$ His coat of arms would also have featured prominently on the walls and contents of the hall.

Shakespeare's treatment of the hall probably followed the tradition of the period, where the internal arrangement of the hall space usually underwent partial or more extensive redesign and modernisation. Archaeological evidence suggests that Shakespeare kept Clopton's open hall, perhaps updating it to his modern tastes, understanding its prestige and unique qualities and retaining it in much the same form for its ability to symbolise his lineage and the stature of his relatively wealthy urban family. ${ }^{41}$ The fate of the open hall within houses of the period differed greatly it was either replaced, altered or retained. Within Shakespeare's New Place the insertion of an upper storey remains a possibility, particularly over the southern service range end above the screens passage. 
Analysis of hall spaces in early modern Bristol has provided a comparative tradition:

The large and sometimes still open symbolic hall remained in Bristol a potent element of merchant housing culture into the 1680s. The genealogy of the open hall as seen in early modern Bristol can be discerned in other leading cities of the fifteenth to seventeenth centuries. ${ }^{42}$

\section{THE LONG GALLERY: SHAKESPEARE'S ADDITION}

Shakespeare introduced a long gallery into New Place as a means to impress his mark on the house and make a statement within Stratford-upon-Avon. This long gallery was not a necessity, but a desirable feature increasingly included in the design of high status houses throughout the period. These galleries:

...evolved from covered walkways and the country houses of the greater gentry built from the early sixteenth century onwards, often include a large gallery as an independent, specialized space intended for walking and magnificent display. But it is only in the later part of the sixteenth century that this fashion for dedicated galleries developed to be enthusiastically embraced by members of the lesser gentry. ${ }^{43}$

Additionally, these long galleries were used for the reception of certain important visitors, the admiration of the views from the windows and as a statement of the owner's stature. The interior of these galleries were known to have been adorned with furnishings such as tapestries, portraiture, benches for resting and glazed windows. ${ }^{44}$

Shakespeare may have used this space as a place to display images of the monarchs he had depicted in his plays and a place to display his newly acquired coat of arms:

Portraits of Tudor monarchs, for example, were easily available through reproductions and there was a vogue well into the seventeenth century for the merchant classes and the lesser gentry to display pictures in their houses. ${ }^{45}$

\section{THE COURTYARD INN AND PERFORMANCE SPACE POSSIBILITIES}

In the appearance of New Place, Shakespeare may have seen many similarities with courtyard inns. These inns were to be found across the country but they were particularly prevalent in the affluent south. There were many courtyard-inn theatres in London, some of these had specially adapted permanent stages, examples of these are the Bell and the Cross Keys in Gracechurch 
Street, the Bull in Bishopsgate and the Bel Savage outside Ludgate. ${ }^{46}$ These were open to audiences of all social classes and backgrounds.

Acting companies increasingly travelled around the country. Throughout Shakespeare's time in London, touring was a part of an acting company's repertoire. The primary performance venues in Stratford were the corporation properties although the inns may have provided additional venues from that of the Guild. The Guild Hall provided the location for the 'command' performance; an initial viewing required by the Stratford Guild as a means of assessing it prior to authorisation at other performance venues in the town.

The Guild Hall is recorded as being:

...the receiving venue-or one of the venues- for professional theatre in Stratford in the years 1568-1597 (and occasionally thereafter), a period when payments for more than 30 visits to the town by travelling companies are recorded. ${ }^{47}$

After 1600 an increasing amount of restrictions were placed on the visiting acting companies and fines were introduced to dissuade and limit the large numbers of performances. Within Stratford, playing was banned from 1597 on corporation property, which meant that 'professional' companies could not obtain a licence. The Guild Hall venue was no longer used but it is likely that other venues took its place.

Other possible locations for performances may have included the town's inns. The main inns of suitable size were situated in Bridge Street, these were the Bear and the Swan and these were known to have been used by the Borough Council for entertaining, a least until 1597. Based on other recorded examples across the country 'it is not unlikely that visiting companies would have taken the opportunity to play at one or other of the inns in whatever accommodation each afforded. ${ }^{48}$

The Stratford Guild and public venues such as inns were not the only alternatives open to travelling players for earning their wages. As Keenan records from research undertaken on other provincial centres:

professional touring players did not confine themselves to performing in urban, public venues, performances were also staged in private town and country houses. Indeed, for 
many acting companies private house companies were an important and lucrative alternative to public, urban productions... ${ }^{49}$

The internal layout and local status of New Place provides us with a number of possibilities for its use. It had the potential and physical space for hosting private performances by the travelling players. Being one of the largest privately owned town houses in Stratford-upon-Avon, with enough space both internally in the hall and externally in the courtyard, New Place would have been a plausible location for the setting of performances, especially after 1597 given the personal interests of its owner and the banning of all theatrical performances on civic properties.

It is interesting to note the known dimensions of the inn yards of London in comparison to New Place. The dimensions of these yards were large enough to accommodate a significant paying audience and justify the performance. The Bull was 1,625 square feet (150.97 square metres) and the Cross Keys 1,600 square feet (148.64 square metres) ${ }^{50}$, these were larger, but not significantly so, than the approximate 1335.25 square foot (124.05 square metres; $45.11 \mathrm{ft} \mathrm{x}$ $29.6 \mathrm{ft}$ or $13.75 \mathrm{~m} \times 9.02 \mathrm{~m}$ ) of New Place.

(Figure 11)

Inns which had buildings arranged around an enclosed central courtyard provided the ideal space for performance. Many courtyard inns also contained galleries on the first floor, these were inward looking and provided a more lucrative viewpoint for the audience watching the performance. It has not been possible to identify, archaeologically, any evidence of the first floor of New Place, so the existence of galleries can only be guessed at. However, as a means of accessing rooms on the first floor, galleries would have provided quick access to the rooms, bypassing the need to move through a sequence of rooms to access the required location and they are therefore a possibility. ${ }^{51}$

The presence of a courtyard would have brought seclusion to rearmost areas of the house, giving Shakespeare the opportunity to write and develop his ideas in relative privacy. He may also have been able to use the house as place in which he was able to rehearse, perform and present his new works to audiences. With the gatehouse door locked, a courtyard also provided an escape and place of privacy from the busy thoroughfare of Chapel Street. 


\section{JOHN SHAKESPEARE, WILLIAM'S FATHER}

Inevitably, William Shakespeare's immediate family had a direct influence on his desire to succeed and become wealthy. His father John was an ambitious and hard-working individual who rose to become a respected merchant (dealing specifically in gloves and wool), landholder and a member of Stratford-upon-Avon's ruling elite, from his background of apprentice glover and leather tanner. Ultimately, he became a Stratford-upon-Avon guild member and later in 1568, a Bailiff (the equivalent of mayor). John Shakespeare and his wife Mary Arden had eight children, William was their first boy and the first to live beyond infancy. Their family home in Henley Street, Stratford-upon-Avon, doubled as the centre of his father's business, with workshops on the ground floor. ${ }^{52}$

It has long been the assumption that from 1577 John's fortunes and reputation fell into decline, leading to John foregoing his official duties as an alderman and being removed from the council in 1586. On the subject of John's lost wealth, much has been written. It was this supposed decline which has been said to have influenced Shakespeare's desire to amass his fortune and restore his father's name in response to his father's loss. However, recent and revised analyses of John's personal circumstances suggest his wealth was never lost but was disguised as a means of continuing his various business ventures. What has become apparent, is that John was a successful, self-made man whose standing in Stratford-upon-Avon voluntarily altered as a result of changes in legislation and regulation that restricted those who dealt in wool. ${ }^{53}$

\section{SHAKESPEARE'S ATTEMPTS TO SECURE THE FAMILY STATUS}

Shakespeare lived in a class-conscious society and he was very aware of the importance of social enhancement and his family's position within society. The Shakespeare family had long been balancing on the borderline between the prosperous bourgeoisie and the minor gentry and through his business fortunes, Shakespeare found himself in a position to cement this status.

A year prior to the purchase of New Place, Shakespeare embarked on the journey which was to see himself and his father become regarded as wealthy landed gentlemen. In 1596 Shakespeare went to the College of Arms in London to apply for a coat of arms and gentlemen status both for his father, preliminary enquiries for which were made 20 years earlier but had 
halted. Shakespeare was himself deeply invested in this process and in gaining reputation as a gentlemen. Newly discovered 17th-century depictions of the coat of arms associate it with 'Shakespeare the player' confirming that contemporaries saw the coat of arms as being for William. ${ }^{54}$ This time the application was successful and his father was duly rewarded with the coat of arms and prestigious status of gentleman. The assumed status which came as a result of this was then acknowledged by future ancestors of John, including William who became a second-generation gentleman. ${ }^{55}$ The acquisition of this coat of arms brought with it the right to put it on conspicuous display. The usual locations for this would have included his portable and permanent home contents and in particular, above the entrance to his house. Shakespeare would have desired a residence befitting for his newly acquired gentleman's status and DuncanJones believes that the purchase formed part of the 'larger plan to turn himself into a gentleman,56 (Fig. 12).

(Figure 12)

\section{REASONS BEHIND THE CONSTRUCTION AND PURCHASE OF NEW PLACE BY CLOPTON AND SHAKESPEARE}

Shakespeare would have appreciated the association between himself and the eminent character of Hugh Clopton. It is highly likely that it was widely known throughout Stratford-upon-Avon that this was the great house of Hugh Clopton. His public works undertaken at Holy Trinity church, the Guild Chapel and the bridge over the Avon had ensured his name was immortalized. Shakespeare would have known about the origins of the house and walked past it on a daily basis on his route to school. Perhaps he developed his love of the house from this early age.

Shakespeare and Clopton both had personal reasons behind their investment in New Place, however there were probably several shared motivations, in spite of the progress of time between the lives of these two men. The choices of these two individuals would have centred on how they wanted to outwardly present themselves.

William Shakespeare and Hugh Clopton were born 100 years apart and yet they held many similarities, perhaps influencing the reasoning behind their construction and purchase of New Place. Both men were from distinguished Warwickshire families, and were of reputable descent and both continued to remember their origins and support their home town, even after they had 
made their fortunes in London. In doing this they achieved much of what they set out to do. Like Clopton, Shakespeare was able to bring prominence to his family name, through his personal achievements, his name is synonymous with Stratford-upon-Avon and he has become its most famous son.

Shakespeare's immediate family were of an aspiring middle-class sort, they were people with money, though the Shakespeare family forebears, were of farming stock. Perhaps the superior social standing of the Hathaway's and the Arden's also had an influence Shakespeare's desire to further his social position. William, like his father John before him, wanted the Shakespeare family name to be remembered for its noble achievements. The purchase of New Place helped Shakespeare increase his social status. Clopton's ancestry was very different, his family roots were already firmly established in the landed gentry, which could be traced back several hundred years.

In purchasing New Place, Shakespeare was thinking of his obligations and of the future for both himself and his family, it also made sense to think about having a place to retire to. More than this though, New Place would have been the perfect place for his wife and daughters (and potentially his extended family) to live comfortably, and in its purchase he was able to perhaps ease his guilt for living away from home from his family for such extended periods. ${ }^{57}$

\section{CLOPTON AND SHAKESPEARE'S MERCANTILE CONNECTION}

Hugh Clopton and the Shakespeare family were both heavily invested in merchant activities, specifically the trading of wool and wool cloth, to generate their income. Hugh Clopton was able to accumulate his vast wealth through his merchant activities in London and the continent. Whist he was merchant of the staple, much of the wool and wool cloth he traded in would have been supplied from the markets of Stratford-upon-Avon and originated from the fields of Warwickshire. The trade in wool and wool cloth continued to be England's primary economic export and throughout the later decades of the 15th century and into the early-16th century it was consistently traded through a heavily regulated professional guild. ${ }^{58}$

An upheaval in the regulated wool markets in the 16th century saw a rise in the wool-broking business, this saw traders outside of the merchant guild being able to share in the fortunes of the profession. John Shakespeare was one such wool dealer. Glovers and leather traders were, 
for many years legally permitted to sell the wool taken from processed animal hides. Traders such as John Shakespeare:

...had sufficient wealth to finance purchases and contacts, created through service as bailiffs of mayors, to place the commodity with manufacturers and exporters. ${ }^{59}$

The rise in the demand for wool cloth away from raw wool saw a growth in the wool-broking business. John saw this opportunity and the wealth he accumulated in his latter years was as a result of the wool-broking and money lending activities he had invested in. ${ }^{60}$ Rather than losing his wealth after a series of financial difficulties, John Shakespeare proceeded to voluntarily withdraw from public life when his successful, but unregulated wool-broking business became threatened by changes in legislation and regulation, which sought to restrict those who dealt in wool. ${ }^{61}$

Continued changes in the wool markets forced the export trade to be concentrated through the London Ports, consequently these developments became a detriment to John Shakespeare's regional business. He would have required a representative in London, someone who was astute enough to undertake his merchant trading from afar. David Fallow proposes that William Shakespeare first made his move to London as a businessman on behalf of his family business, rather than for his theatrical abilities. As a means to continue with the wool-broking business the Shakespeare's needed a London representative. As Fallow states:

William Shakespeare disappears from the record for seven years, the exact term of a traditional apprenticeship, and surfaces in London exactly where and when contacts in the wool trade would have been vital to the survival of the family business. Given John Shakespeare's relative market position in the English wool broking scene, the probability is that William first went to London as a businessman rather than as an impoverished poet. ${ }^{62}$

So, it is plausible that William Shakespeare himself is likely to have been more closely invested in his father's mercantile businesses than once previously believed.

Whatever the extent of Shakespeare's involvement, he would certainly have had an affinity with merchant activities and being the family business he would have had to show a keen awareness. New Place would have provided Shakespeare with a direct connection to Stratfordupon-Avon's most enduring and successful merchant. This grand medieval merchant's house 
would also have provided his family with a historically influential connection with the merchants of the guild, thus ensuring credibility. Shakespeare would have held merchant sympathies, being from a merchant family, perhaps even being involved himself upon his arrival in London. The purchase of New Place, perhaps the foremost example of a merchant house in Stratford-upon-Avon, gave Shakespeare the opportunity to firmly establish his family's status.

\section{CONCLUSIONS}

William Shakespeare chose to purchase New Place for many reasons, not least its significant location, character, status and local prestige. New Place was a statement, it was the largest independently owned residential property in Stratford-upon-Avon and was original and unusual in its layout. It was the only example of a courtyard house in the town and it achieved fame and notoriety in its own lifetime, becoming culturally important to its residents. The significance of New Place is highlighted when, along with other notable landmarks in Stratford-upon-Avon, it was mentioned in Leyland's Itinerary from the 1540s. Hugh Clopton's house would have been desirable to William Shakespeare for its visual attractiveness, its status and for the physical association it held. New Place represented the place where his own social status and personal aspirations could be realised while at the same time giving his home life a focus and stable future. New Place provided Shakespeare with the location where he could firmly establish himself as a resident and representative of Stratford-upon-Avon.

New Place was the place sought out by Shakespeare to use as a place of work, domestic life, entertainment and relaxation. It can be regarded as physical evidence of the attempt by William Shakespeare to elevate the status of his family through inheriting the associations of Hugh Clopton.

For Shakespeare, New Place represented a home base and a secure investment away from the fluctuating fortunes of the capital. It was impressively built and markedly different from any other properties in Stratford. Shakespeare renovated it for the purposes of individualizing it to increase its stature.

The location, size and ancestry of New Place was important to Shakespeare. As a home, it was large enough for a family both to entertain and to undertake business and work. It was also at 
the social centre of town, it was close to the Guild Chapel, the markets, school, his family home and the main thoroughfare leading out into the country.

For Hugh Clopton, the purpose of the layout and structure of New Place was to reflect the sentiment of the late-medieval gentry and impress his standing within society. The type of building he constructed, with its internal courtyard, gatehouse and hall, evolved to have different implications in Elizabethan society. By purchasing New Place, Shakespeare was exploiting both the implied status of New Place and the achievements of Hugh Clopton, its past architect and owner. He viewed it practically as a residence suitable for a playwright, London theatre player and merchant's son. He was also able to use it to celebrate his passion of history and his nostalgia for the world of his grandparents' time and his parents' childhood. The building of New Place become his own link to his ancestors and the outward expression of his aspirations and achievements.

A further theme only touched upon here, but which is deserved of future consideration, is that of the influence of different agencies upon Shakespeare's decision to purchase New Place. This purchase may have been as a result of several other influences, not least that of his wife Anne. Other members of his immediate and extended family may also have had an involvement, particularly as they are more likely to have spent significantly longer periods at the property than Shakespeare himself. Ultimately, the size of the household, and the views of those who would dwell in the house may have been additional deciding factors in Shakespeare's decision.

\section{ACKNOWLEDGEMENTS}

The author would like especially to thank Paul Edmondson for his expert help, advice and revisions; Kevin Colls for his suggestions throughout and support with the illustrations and Mairi Macdonald for the use of her extensive research materials. Additional thanks go to Phillip Watson whose reconstruction drawings have been reproduced here and have greatly enhanced this paper. I would also like to thank all those who made the Dig for Shakespeare project possible including all the staff and volunteers of the Shakespeare Birthplace Trust.

\section{ENDNOTES}


1 Jones 2012, 209.

${ }^{2}$ Wood 2016, xviii.

${ }^{3}$ Edmondson, Colls \& Mitchell 2016.

${ }^{4}$ Shapiro 2005, 258. Shapiro 2015, 134.

${ }^{5}$ Edmondson, Colls \& Mitchell 2016.

${ }^{6}$ Brunskill 1971, 98.

${ }^{7}$ Giles, Masington \& Arnott 2012.

${ }^{8}$ Macdonald 2016.

${ }^{9}$ Macdonald 2016.

${ }^{10}$ Copy of the Will of Hugh Clopton Citizen, Mercer and Alderman, 14th September 1496, Shakespeare Birthplace Trust Archives (TR46/2/1)

${ }^{11}$ Macdonald 2016.

12 Macdonald 2016.

${ }^{13}$ Leyland 1907 [c. 1540].

${ }^{14}$ Leyland 1907 [c. 1540].

${ }^{15}$ Leyland 1907 [c. 1540].

${ }^{16}$ Slater 1997, 42.

${ }^{17}$ Emery 2012, 65.

${ }_{18}^{18}$ Pantin 1962, 208; Leech 2014, 69.

${ }^{19}$ Pearson 2009: 4.

${ }^{20}$ Brunskill 1971, 98.

${ }^{21}$ Schofield and Vince 2003, 88.

${ }^{22}$ Bentley 1913, 22.

${ }^{23}$ Halliwell-Phillipps 1864, 10.

${ }^{24}$ Schoenbaum 1985, 16.

${ }^{25}$ Greer 2007, 210.

${ }^{26}$ Laoutaris 2014, 320.

${ }^{27}$ Bearman 2016, 167.

${ }^{28}$ Edmondson, Colls \& Mitchell 2016, 119.

${ }^{29}$ Bearman 1994, 18.

${ }^{30}$ Shapiro 2005, 269.

${ }^{31}$ Duncan-Jones 2001, 121.

32 Theobald 1733, XIV.

${ }^{33}$ Cousins 2009, 20.

${ }^{34}$ Scheil 2015, 63.

${ }^{35}$ Edmondson, Colls \& Mitchell 2016, 111.

${ }^{36}$ Vertue 1737, British Library, Portland Loan 29/246:18.

${ }^{37}$ Coope 1986, 47-8.

${ }^{38}$ Chambers 1930 vol. 2, 96.

${ }^{39}$ Eccles 1961, 57-8.

${ }^{40}$ Leech 2000, 6-7.

${ }^{41}$ Leech 2000, 6-7.

${ }^{42}$ Leech 2000, 3.

${ }^{43}$ Hamling 2010, 5.

${ }^{44}$ Coope 1986, 47.

${ }^{45}$ Edmondson, Colls \& Mitchell 2016, 149.

${ }^{46}$ Manley 2008, 192.

${ }^{47}$ Mulryne 2012, 171.

${ }^{48}$ Mulryne 2012, 193.

${ }^{49}$ Keenan 2002, 66.

${ }^{50}$ Manley 2008, 192.

${ }^{51}$ Pantin 1961, 166-9.

${ }^{52}$ Fallow 2015, 27.

${ }^{53}$ Fallow 2008, 259.

${ }^{54}$ Schuessler, 2016.

${ }^{55}$ Cousins 2009, 18

${ }^{56}$ Duncan-Jones 2001, 85.

${ }^{57}$ Shapiro 2005, 268.

${ }^{58}$ Steane 1985, 248. 


\footnotetext{
${ }^{59}$ Fallow 2015, 31.

${ }^{60}$ Fallow 2008, 258

${ }^{61}$ Fallow 2008, 31.

${ }^{62}$ Fallow 2015, 38.
}

\section{BIBLIOGRAPHY}

Bate, J. 2008, Soul of the Age: The Life, Mind and World of William Shakespeare, London: Viking.

Bearman, R. 1994, Shakespeare in the Stratford Records, Stroud: A. Sutton \& Shakespeare Birthplace Trust.

Bearman, R. (ed.). 1997, The History of an English Borough. Stratford-upon-Avon 1196-1996, Stroud: Sutton \& Shakespeare Birthplace Trust.

Bearman, R. 2016, Shakespeare's Money: How much money did he make and what did this mean?, Oxford: Oxford University Press.

Bentley, R. 1913, The will of Thomas Bentley M.D. Second president of the Royal College of Physicians and doctor to King Henry VIII: With a brief note on his career, Guildford: Billing.

Bevington, D. 2002, Shakespeare, Oxford: Blackwell Publishing.

Brunskill, R.W. 1971, Illustrated Handbook of Vernacular Architecture, London: Faber \& Faber.

Chambers, E.K. 1930, William Shakespeare: A Study in Facts and Problems, 2 vols, Oxford: Clarendon Press.

Coope, R. 1986, 'The "Long Gallery": Its Origins, Development, Use and Decoration', Architectural History 29, 43-72 \& 74-84.

Cousins, A.D. 2009, The Shakespeare Encyclopaedia, London: Apple Press.

Dotterer, R. 1985, Shakespeare: text, subtext and context, London:, Susquehanna University Press.

Duncan-Jones, K. 2001, Ungentle Shakespeare: Scenes from his life, London: The Arden Shakespeare.

Eccles, M. 1961, Shakespeare in Warwickshire, Madison: University of Wisconsin Press.

Edmondson, P., Colls, K. \& Mitchell, W. 2016, Finding Shakespeare's New Place: An Archaeological Biography, Manchester University Press.

Edmondson, P. \& Wells, S. (eds) 2008, The Shakespeare Circle: An Alternative Biography, Padstow: Cambridge University Press. 
Emery, A. 2012, Discovering Medieval Houses, Oxford: Shire Publications Ltd.

Fallow, D. 2008, 'Like father like son: Financial practices in the Shakespeare family', Studies in Theatre and Performance, 28:3, 253-63.

Fallow, D. 2015, 'His father John Shakespeare' in Edmondson, P \& Wells, S (eds) 2015, 2639

Giles, K., Masinton, A. \& Arnott, G. 2012, 'Visualising the Guild Chapel, Stratford-uponAvon: digital models as research tools in buildings archaeology', Internet Archaeology 32 <http://intarch.ac.uk/journal/issue32/1/toc.html> [Accessed 15th November 2017].

Greenblatt, S. 2004, Will in the World: How Shakespeare became Shakespeare, London: Jonathan Cape.

Greer, G. 2007, Shakespeare's Wife. London: Bloomsbury.

Halliwell-Phillipps, J.O. 1864, An Historical Account of the New Place, Stratford-upon-Avon, the Last Residence of Shakespeare, London: J.E. Adlard.

Hamling, T. 2010. 'New Place', Birmingham: The Shakespeare Institute, University of Birmingham, talk.

Jones, O. 2012, 'The Queens men in Stratford and the troublesome reign of John, king of England' in Mulyryne J.R (ed) 2012, 207-224.

Jope, E.M. 1961, Studies in Building History, Long Acre: Odhams.

Keenan, S. 2002, Travelling Players in Shakespeare's England, Basingstoke: Palgrave Macmillan.

Laoutaris, C. 2014, Shakespeare and the Countess: The battle that gave birth to the Globe. New York: Penguin Books.

Leech, R. 2000, 'The symbolic hall: Historical Context and Merchant culture in the Early Modern City’, Vernacular Architecture 31:1, 1-10.

Leech, R. 2014, The Town House in Medieval and Early Modern Bristol, volume 1. London: English Heritage.

Leyland, J. 1907 [c.1540], The Itinerary of John Leland in or about the years 1535-1543, ed. by L. Smith, London: George Bell and Sons.

Macdonald, M. 2016, 'Hugh Clopton', Oxford Dictionary of National Biography, $<$ http://www.oxforddnb.com/> [Accessed $15^{\text {th }}$ November 2017].

Manley, L. 2008, 'Why Did London Inns Function as Theaters?', Huntington Library Quarterly 71:1, 181-97. 
Mulryne, J.R. 2012, 'Professional Players in the Guild Hall, Stratford-upon-Avon, 1568-1597' in Mulryne, J.R. (ed) 2012, 1-10.

Mulryne J.R. (ed.) 2012, The Guild and Guild Buildings of Shakespeare's Stratford: Society, Religion, School and Stage, Cambridge: Ashgate.

Pantin, W.A. 1961, 'Medieval Inns', in Jope, E.M. 1961, 166-191.

Pantin, W.A. 1962, 'Medieval English town-house plans', Medieval Archaeol. 6:7, 202-39.

Pearson, S. 2009, 'Medieval Houses in English Towns: Form and Location', Vernacular Architecture 40, 1-22.

Scheil, K. 2015, 'His wife Anne Shakespeare and the Hathaways'. In Edmondson, P \& Wells, $\mathrm{S}$ (eds) 2015, 57-70.

Schoenbaum, S. 1985, 'All that is known concerning Shakespeare' in Dotterer, R. 1985, 1530 .

Schuessler, J. 2016, 'Shakespeare: Actor. Playwright. Social Climber', New York Times, <https://www.nytimes.com/2016/06/30/theater/shakespeare-coat-of-arms.html?smid=twnytimesarts\&smtyp $=$ cur\&_r=1> [Accessed $15^{\text {th }}$ November 2017].

Schofield, J. \& Vince, A. 2003, Medieval Towns: The Archaeology of British Towns in Their European setting, London: Continuum.

Shapiro, J. 2005, 1599: A year in the life of William Shakespeare, Croydon: Faber \& Faber.

Shapiro, J. 2015, 1606: William Shakespeare and the year of Lear, Croydon: Faber \& Faber.

Slater, T.R. 1997, 'Domesday Village to Medieval Town: the Topography of Medieval Sratford-upon-Avon' in Bearman, R. (ed) 1997, 30-42.

Steane, J. 1985, The Archaeology of Medieval England and Wales, London: Croom Helm.

Theobald, L. 1733, The Works of Shakespeare, vol. 1, London: J. Tonson, F. Clay, W. Feales \& R. Wellington.

Walter-Hodges, C. 1964, Shakespeare's Theatre, Oxford: Oxford University Press.

Wood, M. 2016, Foreword in Edmondson, P, Colls, K \& Mitchell, W. 2016, xvii-xviii

The site archive, including the finds from the excavations at New Place have been deposited at the Shakespeare Birthplace Trust Museums and Archives, Stratford-upon-Avon.

Department of Humanities and Performing Arts, Staffordshire University, Flaxman Building, College Road, Stoke-on-Trent, ST4 2DE, UK (William.Mitchell@staffs.ac.uk) 
List of Figure Captions

Figure 1: Map of Stratford-upon-Avon in the 16th century, showing buildings mentioned in the text including New Place and Shakespeare's land ownership, the Guild Chapel and Hall, The Swan Inn, The Bear Inn, Shakespeare's family home on Henley Street, Clopton Bridge and Holy Trinity Church. The buildings are laid out on plots which originated in the late-13th century. (Copyright Kevin Colls and William Mitchell)

Figure 2: Modern stained-glass representation of Hugh Clopton within the east window of the Guild Chapel, Stratford-upon-Avon. No contemporary images of Hugh Clopton survive. (Photo and Copyright William Mitchell)

Figure 3: Clopton Bridge looking north-west across the River Avon. (Photo and Copyright William Mitchell)

Figure 4: The site of New Place with excavations in progress in 2012. The Guild Chapel can be seen in in the background. (Photo and Copyright William Mitchell)

Figure 5: The archaeological evidence for New Place, including both Hugh Clopton's original foundations and Shakespeare's additional renovations. The large, shaded area represents the New Place building layout confirmed as a result of the archaeological work. This is depicted in the schematic plan (Fig. 10). (Copyright Kevin Colls and William Mitchell)

Figure 6: North-easterly reconstruction of Hugh Clopton's New Place. The five-bay-front gatehouse range probably housed merchants shops. The Open-Hall building is visible to the rear of the courtyard. These two structures are connected by the service range, which contained the kitchen, buttery and pantry. (Copyright Phillip Watson)

Figure 7: Shakespeare's New Place. The earliest image of New Place by engraver George Vertue from 1737, drawn after the house was demolished. This shows the remodeled frontage and plan of the site. (British Library, MS Portland Loan 29/246, p. 18; reproduced by permission of the British Library Board)

Figure 8: North-easterly reconstruction of Shakespeare's New Place. The front range contains a passage serving four chambers for servant accommodation, a staircase leads of the central corridor to the first floor long gallery. This, and the five roof gables, represent some of the improvements added by Shakespeare. Much of the improvements to the hall and service range were internal. (Copyright Phillip Watson)

Figure 9: South-westerly reconstruction of Shakespeare's New Place. The imposing scale of the hall is clear to see. The silhouette of the Guild Chapel can be seen in the background. (Copyright Phillip Watson)

Figure 10: Schematic ground and first floor plan of Shakespeare's New Place based on historical research and archaeological data. New Place is depicted as a courtyard-style house with a hall, long range, chambers and service range. (Copyright Kevin Colls and William Mitchell) 
Figure 11: Private performance at New Place. The New Place Courtyard with a stage erected, players and invited audience. Based upon reconstructions of performances at the inn-yard theatres (Copyright Philip Watson)

Figure 12: 'Shakespeare the player'. Copy of a coat of arms from $c .1600$ identified in the records of the College of Arms, London. (Copyright Philip Watson) 